\title{
GIS ALATI U OPTIMIZIRANJU OBLIKA I VELIČINE UZORKA ZA INVENTURU ŠUMA VELIKIH TERITORIJALNIH JEDINICA *
}

\section{GIS tools in the optimisation of the shapes and the size of the sample for forest inventory of large territorial units}

\author{
Ahmet Lojo, Besim Balic ${ }^{1}$
}

\begin{abstract}
Izvod
U radu su predstavljene mogućnosti primjene GIS alata u testiranju različitih oblika i broja primjernih površina kao jedinica uzorka za procjenu površina šuma i šumskog zemljišta u inventurama šuma na velikim površinama radi izbora najprikladnije forme uzorka.

Za testiranja kreirani su različiti modeli uzoraka. Primjerne površine unutar traktova klastera su formirane u digitalnom obliku i sistematski raspoređene u kvadratnoj mreži čineći uvijek isti stepen izbora u uzorak. Kao uzorak za testiranje korišćeni su stvarni podaci o površinama šuma sa vektorskih karata koje pokrivaju oko jedne destine površine $\mathrm{BiH}$, odnosno površine šuma i šumskih zemljišta. Sve karte su objedinjene na jednom sloju, čime se došlo do jedne jedinstvene karte svih sastojina.

Metodom preklapanja slojeva uz istovremeno preklapanje njihovih baza podataka, dolazi se brzo do rezultata kakav bi se dobio inventurom šuma. Daljnjim statističkim analizama rezultirajućih baza može se doći do odgovora na pitanje koji je od modela uzorka najreprezentativniji i daje najpribližnije podatke o površinama u odnosu na stvarne.

Ovaj rad u suštini ne daje konačan odgovor, već samo usmjerava na metod kojim se može do njega doći. Metod je korišten u razradi uzorka za provođenje druge državne inventure šuma u Bosni i Hercegovini.
\end{abstract}

Ključne riječi: Inventura šuma, GIS analiza, primjerne površine, trakt,

\begin{abstract}
Possibilities of the GIS tools implementation in testing of the most appropriate shape and optimal number of the exemplary surfaces as the sample units for the assessment of the forest land areas in forest inventories in large areas are presented in this paper.

\footnotetext{
* Rad prezentiran na III simpoziju poljoprivrede, veterinarstva, šumarstva i biotehnologije sa međunarodnim učešćem Strategija razvoja domaće proizvodnje, 28 - 30 septembar/rujan 2005. Sanski Most

${ }^{1}$ Šumarski fakultet Univerziteta u Sarajevu - Faculty of Forestry University of Sarajevo
} 
During the testing, different shapes of the clusters were considered. Exemplary areas in clusters are formed in digital form and systematically distributed in different square grids, keeping the same covered area - the same rate of the selection in the overall sample. For testing, real data on forest areas - vector maps, was used as the sample, this cover about one tenth of the total area of Bosnia and Herzegovina, or the forest area and forest land. All maps were aggregated in one layer, which in turn produced a single map of all cultures.

Using the method of overlapping of layers and at the same time overlapping of their data bases, one can easily get to the result which is similar to that from the forest inventory. Subsequent to further statistical analysis of the resulting bases, it is possible to get the answer which one of the sample models is the most representational and which one presents the closest data to the areas in relation with the real ones.

This paper, in essence, does not provide final answers, but only gives the guidelines for the method by which it is possible to reach these answers. This method was used in the process of methodology development for the second state forest inventory in Bosnia and Herzegovina.

Key words: Forest Inventory, GIS analysis, sample plots, cluster,

\section{Uvod - Preface}

Izbor inventurnog koncepta, odnosno forme i veličine uzorka za snimanje taksacionih elemenata, predstavlja jedno od najvažnijih pitanja prilikom razrade metodike za provođenje inventure šuma, posebno kada se radi o inventurama na velikim teritorijalnim jedinicama, države ili njenih regiona. Pri rješavanju tog pitanja mora se voditi računa o postavljenim ciljevima inventure šuma, vrstama informacija koje treba obezbijediti i potrebnoj tačnosti tih informacija (KOEHL, M. \&PELZ ,D.R., 1991) . Ovaj rad je nastao kao rezultat traženja optimalne forme i veličine uzorka prilikom razrade Metodike za provođenje druge državne inventure šuma u Bosni i Hercegovini.

Da bi inventura šuma mogla odgovoriti postavljenim zahtjevima s obzirom na traženu tačnost dobijenih podataka i informacija o stanju šuma i šumskog fonda uz minimiziranje troškova provođenja, potrebno je unaprijed planirati oblik, broj i nacrt rasporeda primjernih površina koje će se koristiti za procjenu najvažnijih elemenata, kao što su podaci o površinama pojedinih uređajnih i ekološko-proizvodnih klasifikacionih jedinica šuma. Drugim riječima, potrebno je izvršiti optimiziranje uzorka kako s obzirom na oblik i broj primjernih površina tako i s obzirom na njihov međusobni raspored.

Naučna istraživanja i iskustva na tom polju definitivno su dala odgovor na neka pitanja opimalnog uzorka:

a) Uzorak mora biti statistički objektivan i reprezentativan (MIRKovIĆ, D. \& BANKOVIĆ, 1993, SCHIELER, K.\&HAUK, E., 2001); 
b) Kao takav, najbolji je u formi sistematski (ili slučajno) raspoređenih probnih površina (elemenata uzorka) po cijeloj teritoriji koja se obuhvata inventurom (MATIĆ,1965, KoEHL, M.\& PELZ,D.R.,1991, SCHMID-HAAS, ET AL.,1993).

c) Radi smanjenja troškova terenskih radova primjerne plohe se grupišu u traktove (clusters - klasteri) (KROMIDHA, ET AL.,2001, PRETO, 2001).

d) Traktovi trebaju imati toliko ploha da ih je moguće sve premjeriti u jednom danu, čak i ako se sve plohe nalaze u šumi (ili da se u jednom danu mogu premjeriti plohe iz dva trakta).

e) Sama veličina uzorka, odnosno gustina mreže traktova zavisi od tražene tačnosti procjene taksacionih elemenata (LÖTSCH, ET AL.,1973, ZÖHRER, 1980, AKÇA, 2000).

f) Od forme traktova i njihovog prostornog rasporeda $u$ velikoj mjeri zavise troškovi terenskih radova $i$ tačnost procjene pojedinih taksacionih elemenata (KANGAS, A. \& MALTAMO, M., 2006).

Prilikom traženja optimalne forme trakta i broja primjernih ploha unutar njega, slijedili smo navedene postupke.

Pri istoj veličini uzorka, t.j. pri istom procentom obuhvata ukupne površine populacije (šuma i šumskih zemljišta), po svojoj formi traktovi mogu biti jako različiti. Konačni rezultati primjene različitih formi traktova u uzorku u inventurama, ipak rezultiraju različitom tačnošću procjene pojedinih taksacionih elemenata, i, što je najvažnije, različitim finansijskim troškovima za njihovu realizaciju.

\section{Metod rada - Method of work}

Prilikom razrade forme i veličine uzorka analizirane su forme uzoraka primjenjenih u zapadnoevropskim zemljama u posljednjoj deceniji, posebno one koje imaju slične prirodno-vegetacijske uslove kao u BiH. Takođe je analizirana forma uzorka primjenjenog u prvoj inventuri šuma na velikim površinama u BiH.

Pošli smo od pretpostavke da je najbolja forma trakta ona koja uz istu veličinu uzorka daje najveći obuhvat varijabiliteta (broj) različitih tipova vegetacije (MATIĆ, ET AL 1971, SHIVER, B. D.\&BORDERS, B. E., 1996).

Imajući u vidu potrebu utvrđivanja površina šuma na različitim klasifikacionim nivoima šuma i šumskih zemljišta kao jednog veoma varijabilnog obilježja, pristupilo se detaljnim GIS analizama primjene različitih oblika primjernih površina za procjenu površine šuma, sa detaljnošću do nivoa širih i užih kategorija šuma. Kao uzorak i objekt istraživanja za testiranje korišćeni su podaci o površinama šuma - vektorskih karata iz najnovijih planova gazdovanja šumama za osam šumskogospodarskih područja u $\mathrm{F} \mathrm{BiH}$, koja čine međusobno povezan kompleks ukupne površine od 591537,3 ha, sa oko 266000 ha šuma i šumskih zemljišta u državnom vlasništvu (slika 1). To je približno jednoj desetini površine $\mathrm{BiH}$, odnosno površine šuma $\mathrm{i}$ šumskih zemljišta. Sa stanovišta pojave različitih tipova šuma, ovo područje u BiH je najkompleksnije i najheterogenije. 
Sve postojeće vektorske karte su objedinjene na jednom sloju, čime se došlo do jedne jedinstvene karte svih sastojina. Tipovi šuma - gazdinske klase koje se javljaju u ovih osam područja su bile numerisane jedinstvenim šiframa. Tako je svaka sastojina u bazi podataka za ovaj sloj imala odgovarajući podatak o pripadosti tipu šume, koji smo ovom prilikom poistovjetili sa šifrom gazdinske klase. Podaci o površinama svake sastojine, gazdinske klase, uže i šire kategorije šuma i uopšte površine svih šuma i šumskog zemljišta su tako za pomenuta područja unaprijed bili poznati.

To nam je omogućilo testiranje različitih oblika traktova za procjenu površina pojedinih kategorija šuma koje su zastupljene u okviru objekta istraživanja.

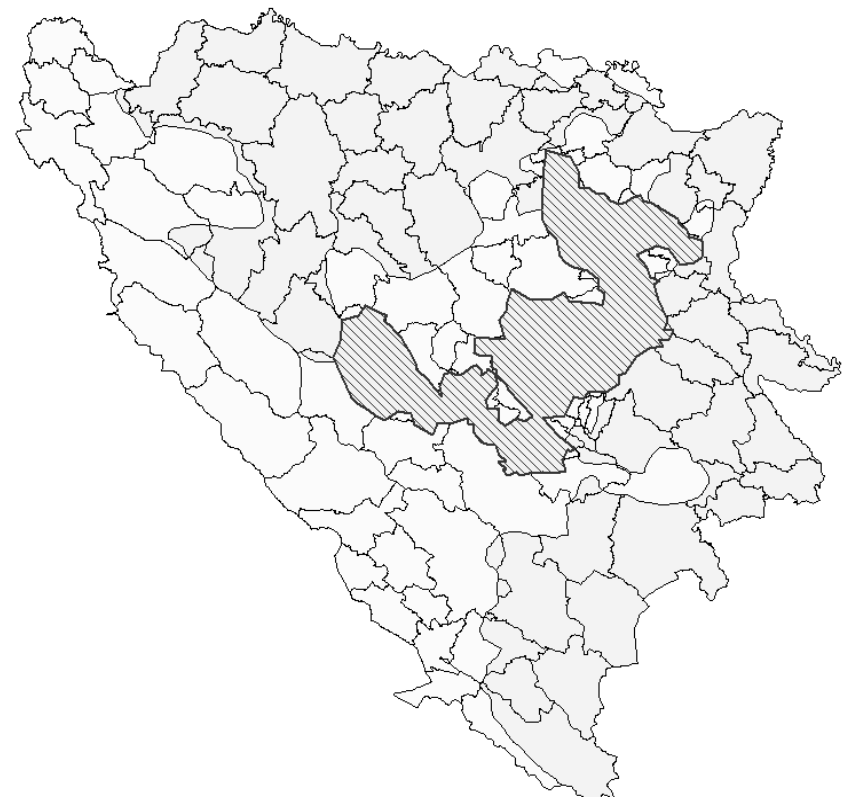

Slika 1. Objekt istraživanja u BiH (tzv. «primarni sloj» na koji su prenesene sve sastojine Fig. 1. View of research areain $B \& H$-layer in GI- system with all forest stand

Naša istraživanja su se fokusirala na rješavanje tri postavljena zadatka:

- Da li postoji signifikantna razlika u procjeni površine šuma i šumskog zemljišta ako se odabrani (određeni) oblik primjerne površine u okviru sistematskog rasporeda različito orijentiše (usmjeri)?

- Koji od testiranih oblika primjernih površina uz istu stopu izbora (istu veličinu uzorka) daje najprihvatljivije rješenje s obzirom na veličinu greške procjene površina šuma?

- Da li je predviđeni način računanja površina i greške površina pojedinih kategorija šuma u državnoj inventuri šuma adekvatan i primjenjiv?

Za rješavanje navedenih zadataka pribjeglo se korištenju isključivo GIS alata kojim se na brz i efikasan način može obraditi tako zahtjevan i obiman posao. 
$\underline{\text { Prvi zadatak }}$

\section{Rezultati rada - Results of work}

U okviru rješavanja prvog postavljenog zadatka, prvo je bilo potrebno dati odgovor na pitanje da li je najveće variranje tipova vegetacije u $\mathrm{BiH}$, prema ranijoj pretpostavci (MATIĆ, 1965, MATIĆ,V. ET AL., 1971) u pravcu $18^{\circ} 26^{\prime}$ u odnosu na pravac sjevera?

Da bi smo riješili ovo pitanje, u GIS okruženju su formirana 4 sloja (L1, L2, L3, L4 tabela 1), koji su sadržavali poligone - neprekidne pruge širine $1 \mathrm{~m}$, sistematski raspoređene preko ,primarnog" sloja sastojina. Na svakom sloju pruge su bile na istim i međusobno jednakim razmacima od $1 \mathrm{~km}$, ali su bile različite orijentacije u odnosu na pravac sjevera (S-J, I-Z, SI-JZ sa zaokretanjem istočno od sjevera - azimut $18^{\circ} 26^{\prime}$, SZ-JI sa azimutom $108^{\circ} 26^{\prime}$. Ove dvije zadnje orijentacije su naknadno izrađene u još po jednoj kombinaciji, četiri puta gušćeg rasporeda pruga na međusobnim odstojanjima od $250 \mathrm{~m}$ (L3 i L3 b, L4 i L4 b).

Služeći se GIS funkcijom „preklapanja poligona“ (overlay function), sloja svih sastojina (koje u ovom slučaju predstavljaju poligone) i pojedinih slojeva primjernih pruga, dobijaju se novi poligoni kao presjeci poligona pruga i poligona sastojina (LONGLEY, ET AL., 2001, LOJO, A.\& PONJAVIĆ, M., 2004).

Rezultati preklapanja su predstavljeni u tabeli 1 . Što je broj kreiranih novih poligona (presjeka) veći i što je je njihova prosječna dužina manja, to je obuhvat varijabiliteta tipova šuma bolji.

Tabela 1. Rezultati provedene procedure preklapanja različito usmjerenih pruga sa «primarnim slojem» - slojem svih sastojina

Table 1. Results of GIS overlay of created layers of strips and all forest stands leyer

\begin{tabular}{|c|c|c|c|c|}
\hline $\begin{array}{c}\text { Pruge } \\
\text { strips }\end{array}$ & $\begin{array}{c}\text { Azimut } \\
\text { Strip orientation } \\
\left({ }^{\circ}\right)\end{array}$ & $\begin{array}{c}\text { Broj kreiranih } \\
\text { presjeka } \\
\text { Number of } \\
\text { intersections }\end{array}$ & $\begin{array}{c}\text { Ukupni presjek } \\
\text { Total area of } \\
\text { intersections } \\
\mathrm{m}^{2} \text { ili } \mathrm{m}^{\prime}\end{array}$ & $\begin{array}{c}\text { Prosječna dužina } \\
\text { dionice } \\
\text { Average length of } \\
\text { intersections } \\
(\mathrm{m})\end{array}$ \\
\hline L1 & $0^{\circ} 0^{\prime}$ & 2188 & 543425,26 & 248,36 \\
\hline L2 & $90^{\circ}, 0^{\prime}$ & 2163 & 515715,09 & 238,43 \\
\hline L3 & $18^{\circ} 26^{\prime}$ & 2169 & 519010,37 & 239,29 \\
\hline L4 & $108^{\circ} 26^{\prime}$ & 2202 & 527569,58 & 239,59 \\
\hline L3 b & $18^{\circ} 26^{\prime}$ & 8764 & 2093076,65 & 238,83 \\
\hline L4 b & $108^{\circ} 26^{\prime}$ & 8944 & 2101152,01 & $\mathbf{2 3 4 , 9 2}$ \\
\hline
\end{tabular}

Na bazi prvih analiza došlo se do zaključka da najveći varijabilitet nije kako je ranije potvrđeno SI-JZ pod uglom od $18^{\circ} 26^{\prime}$, već upravo okomito na prethodni pravac, tj. SZ-JI sa azimutom $108^{\circ} 26^{\prime}$. To je vidljivo iz tabele 1 , jer je najkraća prosječna dužina presjeka je pruge $\mathrm{L} 4 \mathrm{~b}$.

Ipak, do statistički značajnih razlika u varijabilitetu tipova vegetacije, po različitim pravcima nismo došli. 


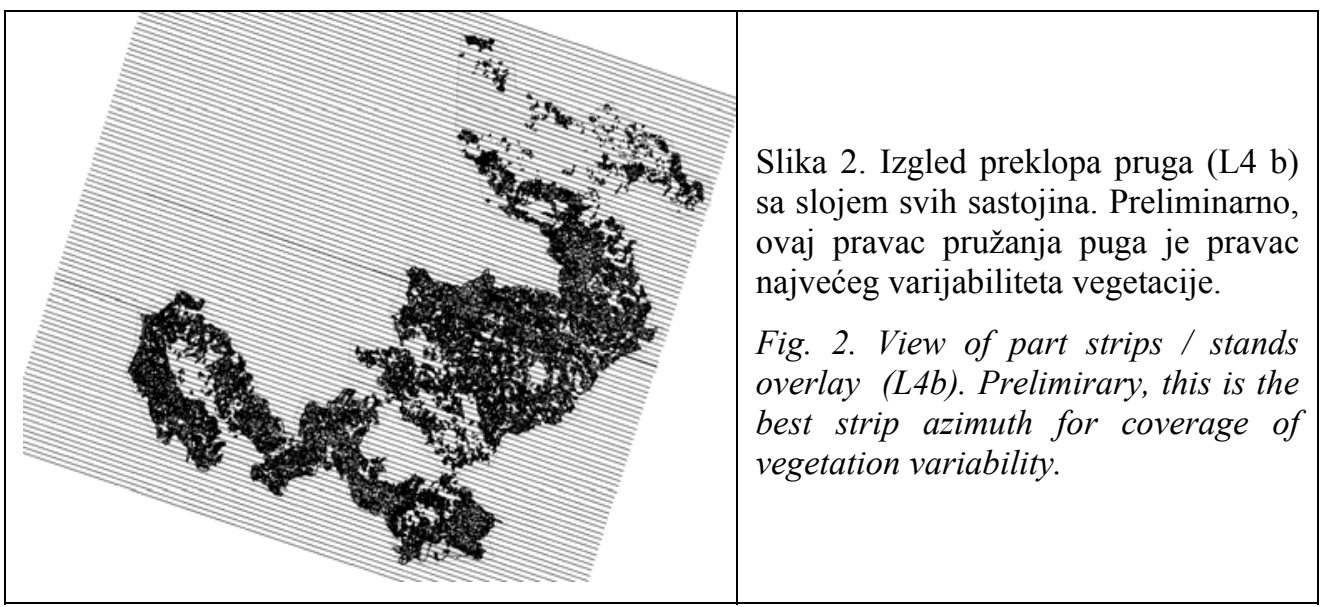

\section{Drugi zadatak:}

U rješavanju drugog zadatka - procjeni najprikladnijeg oblika i optimalnog broja traktova kao jedinica uzorka za procjenu površina šuma i šumskog zemljišta, pristupilo se testiranju različitih oblika primjernih površina - traktova na sličan način kao i u prethodnom slučaju.

Za testiranja formirani su sljedeći oblici primjernih površina:

- pravolinijske pruge, već korištene u prethodnoj inventuri (dimenzija širine 20 m a dužine $5,6 \mathrm{~km}$ ) - test 1 i 2 ;

- prelomljene pruge u obliku slova „L“ $\mathrm{u}$ dvije modifikacije (međusobnog razmaka 5,056 km x 5,056 km, širine od $20 \mathrm{~m}$ i 3,0 km x 3,0 km, širine $20 \mathrm{~m}$ ) - test 3,4,5 i 6 ;

- $\quad$ kvadratni oblici pruga sa modifikacijama međusobnog razmaka 3,0 km x 3,0 $\mathrm{km}$ i 2,0 km x 2,0 km (zadržavajući istu širinu pruga od $20 \mathrm{~m}$ ) - test 7 i 8 ;

- krugovi u kvadratnom rasporedu (4 kruga radijusa $\mathrm{r}=25 \mathrm{~m}$ koji se nalaze na jednakom odstojanju na tjemenima kvadrata sa dužinom stranice $200 \mathrm{~m}$ i čine 1 trakt- sa međusobnim razmakom traktova $2 \mathrm{~km} \times 2 \mathrm{~km}$ ) - test 9 .

Veličina pojedinih traktova (dužine njihovih stranica) je računata tako da pri različitoj gustoći kvadratnog rasporeda traktova ukupna površina uzorka (svih stranica traktova) bude ista (vidi tabelu 2 - kolona veličina uzorka). Pri tome smo odlučili da je praktičnije ako se unaprijed odabere gustina mreže traktova, a dužine stranica traktova se odrede računskim putem nego obrnuto, zbog lakše implementacije na terenu takvoga uzorka. Od prvobitne ideje da L traktove kreiramo sa različitim dužinama i orijentacijom njihovih stranica smo odustali, jer nismo utvrdili sistematski značajan pravac pružnja najvećeg varijabiliteta tipova vegetacije, rješavajući prvi zadatak.

Izgled kreiranih traktova u GIS okruženju i njihov djelimičan raspored sa pripadajućom bazom podataka (za selektovani $\mathrm{L}_{1}$ trakt) prikazani su na slici 2., dok su osnovne karakteristike navedenih primjernih površina predstavljenei u tabeli 2. 
Za traktove oblika pruga, oblika L i kvadratnog oblika zadržana je ista stopa izbora (ukupna veličina uzorka), dok je kod sistema krugova stopa izbora bila skoro dva puta manja.

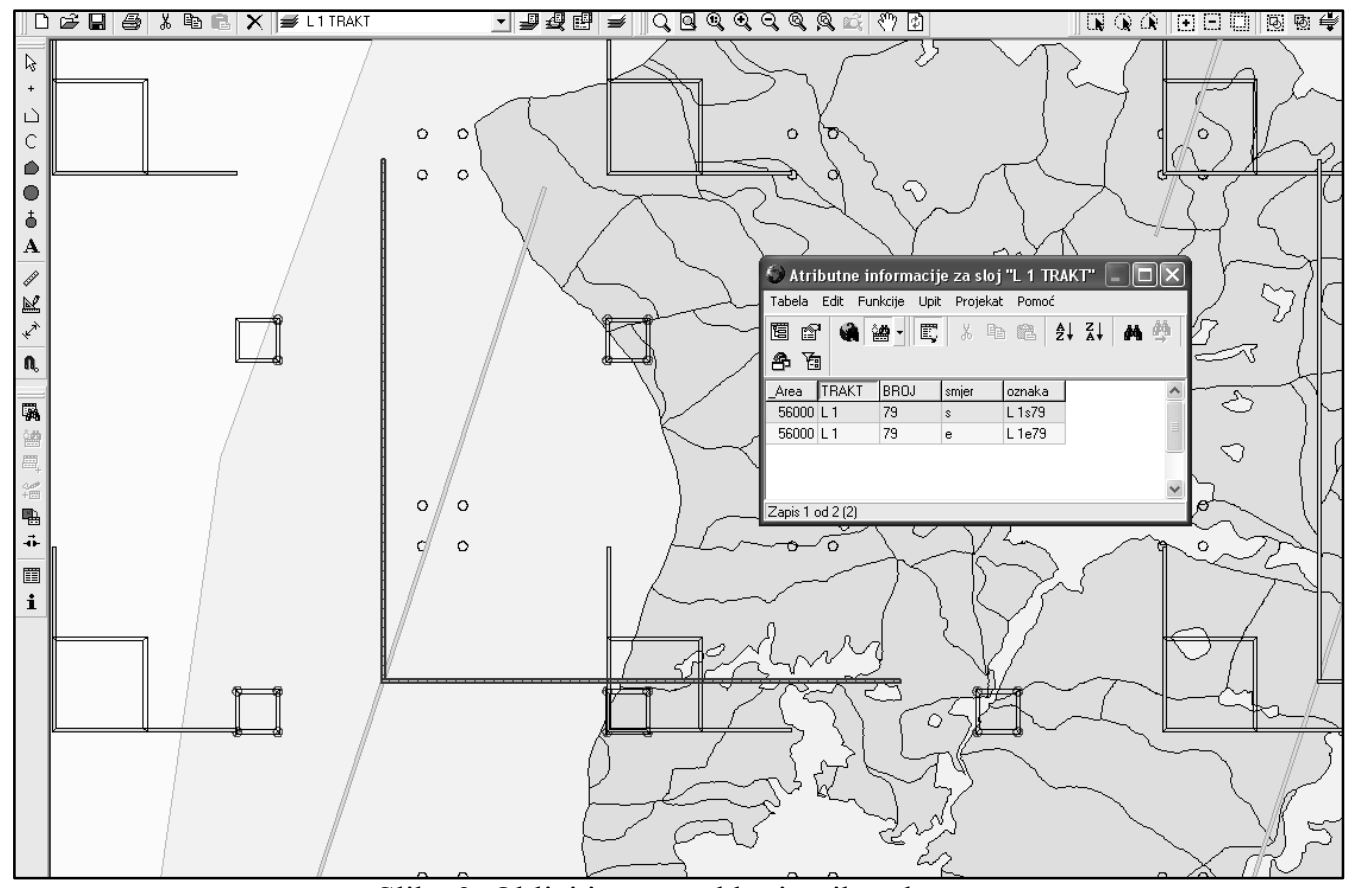

Slika 3. Oblici i raspored kreiranih traktova

Fig 3. Form and spatial distributions of created tracts

U narednoj tabeli. 2 date su osnovne informacije o formiranim traktovima.

Objašnjenja sadržaja tabele:

Testovi 1 i 2 se odnose na linijske pruge sa dva ponavljanja uz pomjeranje njihove mreže prostornog rasporeda. Testovi 3 i 4 odnose se na traktove - pruge oblika slova «L» jednake dužine krakova, sa dva pomjeranja (istog razmaka i površine kao i pruge). Testovi 5 i 6 odnose se na traktove - pruge oblika slova «L» koje imaju manju površinu ali sa većim brojem položenih L-pruga (raspoređenih razmaku $3 \times 3 \mathrm{~km}$ ), takođe u dva pomjeranja. Test 7 odnosi se na traktove oblika kvadrata « $\square$ » koji imaju raspored $3 \times 3 \mathrm{~km}$. Test 8 odnosi se na traktove oblika kvadrata « $\square$ » koji imaju raspored $2 \times 2 \mathrm{k}$. Test 9 odnosi se na trakt krugova u kvadratnom rasporedu $。$ na međusobnom rastojanju od $2 \times 2 \mathrm{~km}$. Za testove 7,8 i 9 nisu provedena dva ponavljanja, odnosno druga pomjeranja već samo jedno. Ova zadnja forma trakta -4 kruga, naknadno je višestruko ponavljana i detaljno analizirana. Ustvari, cilj ovih ponavljanja (pomjeranja) je bio da se vidi kako se mijenja veličina relativne greške procjene (kao mjere variranja površina pojedinih tipova šuma), ako se zadrži ista mreža sistematski postavljenih traktova ali sa novom startnom pozicijom razvijanja kvadratne mreže, tj. novim položajem traktova. 
Tabela 2.-Osnovni podaci o traktovima

Table 2. Basic data about tracts

\begin{tabular}{|c|l|c|c|c|c|c|}
\hline $\begin{array}{c}\text { R.br. } \\
\text { testa } \\
\text { Nb of } \\
\text { trest }\end{array}$ & $\begin{array}{c}\text { Oblik } \\
\text { trakta } \\
\text { Tract } \\
\text { Shape }\end{array}$ & $\begin{array}{c}\text { Gustina } \\
\text { traktova } \\
\text { Tact } \\
\text { net.density } \\
(\mathrm{km})\end{array}$ & $\begin{array}{c}\text { Reprezentuje } \\
\text { površinu } \\
\text { Representig } \\
\text { area } \\
(\text { ha) }\end{array}$ & $\begin{array}{c}\text { Površina } \\
\text { trakta } \\
\text { Tract } \\
\text { sample } \\
\text { area (ha) }\end{array}$ & $\begin{array}{c}\text { Broj } \\
\text { traktova } \\
\text { tracts }\end{array}$ & $\begin{array}{c}\text { Ukupno } \\
\text { uzorak } \\
\text { Sample } \\
\text { total } \\
\text { (ha) }\end{array}$ \\
\hline test 1 & Pruge I & $5,056 \times 5,056$ & 2556 & 11,20 & 233,3 & 2613,36 \\
\hline test 2 & Pruge II & $5,056 \times 5,056$ & 2556 & 11,20 & 229,8 & 2574,33 \\
\hline test 3 & L1 trakt a & $5,056 \times 5,056$ & 2556 & 11,20 & 231,0 & 2586,64 \\
\hline test 4 & L1 trakt b & $5,056 \times 5,056$ & 2556 & 11,20 & 230,9 & 2586,00 \\
\hline test 5 & L2 trakt a & $3,0 \times 3,0$ & 900 & 3,94 & 659,4 & 2600,17 \\
\hline test 6 & L2 trakt b & $3,0 \times 3,0$ & 900 & 3,94 & 655,8 & 2585,79 \\
\hline test 7 & Kvadrat & $3,0 \times 3,0$ & 900 & 3,94 & 660,5 & 2604,32 \\
\hline test 8 & Kvadrat & $2,0 \times 2,0$ & 400 & 1,75 & 1482,0 & 2597,22 \\
\hline test 9 & Krugovi & $2,0 \times 2,0$ & 400 & 0,79 & 1482,1 & 1163,61 \\
\hline
\end{tabular}

Metodom preklapanja slojeva različitih vektorskih sadržaja (sloja sastojina sa slojevima koji sadrže pojedine traktove navedenog oblika i gustine mreže) uz istovremeno preklapanje njihovih, unaprijed kreiranih, baza podataka, dolazi se brzo do rezultata sličnog onom koji bi se dobio terestičkim postupkom, t.j. stvarnom inventurom šuma. Rezultati provedenog testiranja predstavljeni su u sljedećim tabelama:

Tabela 3. Obuhvat varijabiliteta vegetacije (različitih gazdinskih klasa- GK) testovima Table 3. Coverage of vegetation variability (different forest management classes - MC) with different tests

\begin{tabular}{|c|c|c|c|c|c|c|c|c|c|c|}
\hline $\begin{array}{c}\text { Test } \\
\text { tests }\end{array}$ & 1 & 2 & 3 & 4 & 5 & 6 & 7 & 8 & 9 & $\begin{array}{c}\text { Postoji } \\
\text { Exist in real }\end{array}$ \\
\hline $\begin{array}{c}\text { Broj GK } \\
\text { Number of MC }\end{array}$ & 72 & 73 & 72 & 73 & 73 & 74 & 74 & $\underline{76}$ & $\underline{76}$ & $\mathbf{7 8}$ \\
\hline
\end{tabular}

Iz tabele 3 je vidljivo da su najbolji obuhvat varijabiliteta, s obzirom na broj gazdinskih klasa koje su zahvaćene uzorkom, dali testovi 8 i 9. Od ukupno 78 različitih gazdinskih klasa koje zaista postoje u istraživanom (testnom) području, dizajni uzorka pod brojem testa 8 i 9 su ,identifikovali“ 76 . Dvije gazdinske klase koje nisu pronađene su u ukupnoj površini testnog područja bile zastupljene sa vrlo malim procentom (manje od 0,1\%) i koncentrisane na malom prostoru. Interesantno je, da je test 9 dao isti obuhvat varijabiliteta sa skoro dva puta manjom ukupnom površinom uzorkom (obuhvaćenom površinom od svih sastojina) kao i test 8 . Za zadnju formu i dizajn trakta izvršeno je više uzastopnih ponavljanja da bi se provjerio ovaj kvalitet.

Daljom analizom dobijenih rezultata preklapanja podataka u internoj bazi podatka, a na osnovu površina pojedinih presjeka traktova i sastojina, njihove površine i pripadnosti pojedinin gazdinskim klasama, došli smo do podataka o procjenjenim površinama pojedinih širih kategorija šuma, kao rezultata pojedinih testova (primjene različitih formi i dizalna traktova). 
Budući da smo poznavali podatke unutar istraživanog područja, bilo je moguće sagledati odstupanja procjenjenih od stvarnih veličina površina. Rezultati provedenih analiza prikazani su u tabelama 4 i 5 .

Tabela 4. Procentualni udjeli širih kategorija šuma (Š.K.) u ukupnoj površini ispitivanog područja, različitim testovima i stvarni podaci

Table 4. Area percentange of higher forest kategories $(H C)$ in total tested area per different test, and real data in tested area

\begin{tabular}{|c|c|c|c|c|c|c|c|c|c|c|}
\hline \multirow{2}{*}{$\begin{array}{c}\text { Š.K. } \\
\text { šuma } \\
\text { H.C. of } \\
\text { forests }\end{array}$} & \multicolumn{8}{|c|}{$\begin{array}{l}\text { Procjena površine šuma prugama (stacionažom na traktu) } \\
\text { Strip lenght measuring assesment of area }\end{array}$} & \multirow{2}{*}{\begin{tabular}{|c|}
$\begin{array}{c}\text { From } \\
\text { Proport. }\end{array}$ \\
$\begin{array}{c}\text { test9 } \\
\%\end{array}$
\end{tabular}} & \multirow{2}{*}{$\begin{array}{c}\text { Stvarni } \\
\text { udio } \\
\text { Real data } \\
(\%)\end{array}$} \\
\hline & $\begin{array}{c}\text { test1 } \\
\%\end{array}$ & $\begin{array}{c}\text { test } 2 \\
\%\end{array}$ & $\begin{array}{c}\text { test3 } \\
\%\end{array}$ & $\begin{array}{c}\text { test4 } \\
\%\end{array}$ & $\begin{array}{l}\text { test5 } \\
\%\end{array}$ & $\begin{array}{c}\text { test6 } \\
\%\end{array}$ & $\begin{array}{c}\text { test7 } \\
\%\end{array}$ & $\begin{array}{c}\text { test } 8 \\
\%\end{array}$ & & \\
\hline 1000 & 28,56 & 30,30 & 28,59 & 30,61 & 28,97 & 29,07 & 28,44 & 29,03 & 29,18 & 29,37 \\
\hline 2000 & 1,33 & 1,12 & 1,14 & 1,02 & 1,30 & 0,85 & 0,85 & 1,18 & 1,17 & 1,15 \\
\hline 3000 & 2,94 & 2,61 & 3,10 & 3,09 & 2,92 & 3,07 & 2,96 & 3,25 & 3,17 & 3,08 \\
\hline 4000 & 6,01 & 5,77 & 5,80 & 5,20 & 5,09 & 5,06 & 5,15 & 5,62 & 5,58 & 5,65 \\
\hline 5000 & 1,63 & 1,48 & 1,65 & 1,75 & 1,63 & 1,76 & 1,68 & 1,77 & 1,76 & 1,60 \\
\hline 6000 & 2,85 & 2,60 & 2,23 & 2,66 & 2,67 & 2,96 & 3,01 & 2,71 & 2,72 & 2,64 \\
\hline 7000 & 1,45 & 1,45 & 1,75 & 1,62 & 1,48 & 1,70 & 1,57 & 1,43 & 1,49 & 1,50 \\
\hline $\begin{array}{l}\text { Sve Š.K } \\
\text { All H.C. }\end{array}$ & 44,77 & 45,33 & 44,26 & 45,95 & 44,06 & 44,45 & 43,66 & 45,00 & 45,07 & 44,98 \\
\hline
\end{tabular}

Tabela 5. -Relativna odstupanja procjenjenih u odnosu na stvarne površine širih kategorija šuma (Š.K.) - veličine stvarne relativne greške procjene po pojedinim testovima.

Table 5: Relative differences between assessed areas of forest categories and real areas of theese categories per particular tests

\begin{tabular}{|c|c|c|c|c|c|c|c|c|c|}
\hline $\begin{array}{c}\text { S.K. } \\
\begin{array}{c}\text { Suma } \\
\text { H.C. of } \\
\text { forests }\end{array}\end{array}$ & $\begin{array}{c}\text { test1 } \\
\%\end{array}$ & $\begin{array}{c}\text { test2 } \\
\%\end{array}$ & $\begin{array}{c}\text { test3 } \\
\%\end{array}$ & $\begin{array}{c}\text { test4 } \\
\%\end{array}$ & $\begin{array}{c}\text { test5 } \\
\%\end{array}$ & $\begin{array}{c}\text { test6 } \\
\%\end{array}$ & $\begin{array}{c}\text { test7 } \\
\%\end{array}$ & $\begin{array}{c}\text { test8 } \\
\%\end{array}$ & $\begin{array}{c}\text { test9 } \\
\%\end{array}$ \\
\hline 1000 & $-2,77$ & 3,15 & $-2,66$ & 4,21 & $-1,38$ & $-1,03$ & $-3,18$ & $-1,17$ & $-0,68$ \\
\hline 2000 & 15,70 & $-2,20$ & $-0,69$ & $-11,41$ & 12,98 & $-26,12$ & $-25,80$ & 3,19 & 1,82 \\
\hline 3000 & $-4,47$ & $-15,13$ & 0,80 & 0,34 & $-5,03$ & $-0,36$ & $-3,76$ & 5,77 & 3,13 \\
\hline 4000 & 6,37 & 2,23 & 2,74 & $-7,88$ & $-9,84$ & $-10,42$ & $-8,81$ & $-0,55$ & $-1,17$ \\
\hline 5000 & 2,24 & $-7,56$ & 3,04 & 9,58 & 2,01 & 9,97 & 5,04 & 10,72 & 9,90 \\
\hline 6000 & 8,15 & $-1,48$ & $-15,33$ & 1,09 & 1,28 & 12,18 & 14,17 & 3,03 & 3,39 \\
\hline 7000 & $-3,30$ & $-3,52$ & 16,79 & 7,85 & $-1,48$ & 13,15 & 4,79 & $-4,41$ & $-0,50$ \\
\hline $\begin{array}{l}\text { Sve Š.K. } \\
\text { All } H . C\end{array}$ & $-0,47$ & 0,78 & $-1,59$ & 2,16 & $-2,05$ & $-1,17$ & $-2,93$ & $\mathbf{0 , 0 5}$ & $\underline{\mathbf{0 , 2 0}}$ \\
\hline
\end{tabular}


Kako je vidljivo iz tabela 4 i 5, na osnovu analiza ovih podataka došlo se do zaključka da su za procjenu površina širih kategorija šuma i šumskih zemljišta najefekivnije površine kružnog oblika, jer se primjenjujući traktove od 4 kruga na rastojanju od 200 $\mathrm{m}$, sa skoro upola manjom površinom obuhvata postiže skoro ista veličina relativne greške procjene koja se postiže i pri primjeni ostalih oblika primjernih površina.

Treći zadatak:

Radi provjere prethodnih zaključaka $\mathrm{i}$ radi provjere pretpostavljenog načina utvrđivanja relativne greške procjene površina pojedinih kategorija šuma, postavljen je veći broj testova odnosno ponavljanja - simulacija inventure po modelu testa 9.

U tu svrhu kreirana mreža traktova od 4 kruga je prije svakog preklapanja sa slojem sastojina pomjerana (smicana) u novi položaj. Smicanje mreže traktova je vršeno po dijagonali kvadrata 2 × $2 \mathrm{~km}$, tako da su svi traktovi bili pomjerani na sjeveroistok za $141 \mathrm{~m}$ u odnosu na njihovu prethodnu lokaciju. Ukupno je izvršeno dodatnih 9 pomjeranja, odnosno preklapanja slojeva-simulacija inventure šuma, te se tako dobilo 10 različitih rezultirajućih baza podataka koje su posebno analizirane s obzirom na tačnost procjene površina pojedinih širih kategorija šuma.

$\mathrm{Za}$ računanje greške procjene površine šuma uzorka korištene su sljedeće formule (KOPRIVICA, 1995):

-Proporcija iz uzorka: ; $p=\frac{F_{M C}}{F_{\text {TOTAL }}}$;

gdje je: $F_{M C}$-površina šire kategorije šume,

$F_{\text {TOTAL }}$-ukupna površina istraživanog područja.

- Standardna greška proporcije: $S_{p}=\sqrt{\frac{p(1-p)}{n}}$;

- Relativna greška proporcije: $m_{p}(\%)=100 \cdot \frac{2 \cdot S_{p}}{p}$.

Izračunate relativne greške procjene površina uzorkom su zatim upoređivane sa stvarnim relativnim greškama procjene površina, $\mathrm{s}$ obzirom da su tačne površine poznate. Rezultati provedenih ponavljanja testa sa traktovima krugova predstavljeni su u tabeli 6 .

Iz tabele 6 je vidljivo da je od ukupno 110 slučajeva izračunata veličina relativne greške procjene u samo 4 puta bila manja od stvarne veličine relativne greške procjene, pri primjeni vjerovatnoće od $95 \%$, čime se potvrđuje da je ovaj metod utvrđivanja veličine relative greške procjene površina pojedinih kategorija šuma sasvim korektan. 
Tabela 6 . Relativne greška procjene površina pojedinih kategorija šuma u 10 ponavljanja preklapanja traktova sa krugovima i sloja svih sastojina.

Table 6. Relative eror od area estimate per forest categories from 10 repeating of test 9 , tract/stands overlay

\begin{tabular}{|c|c|c|c|c|c|c|c|c|c|c|c|}
\hline \multirow{3}{*}{$\begin{array}{l}\text { Kateg. } \\
\text { šume } \\
\text { Forest } \\
\text { categ. }\end{array}$} & \multirow{3}{*}{$\begin{array}{c}\text { Greška } \\
\text { po: } \\
\text { Eror } \\
\text { from: }\end{array}$} & \multicolumn{10}{|c|}{$\begin{array}{l}\text { Ponavljanja testa } 9 \text { sa smicanjem mreže traktova } \\
\text { Repeating of test } 9 \text { with moving of tract network }\end{array}$} \\
\hline & & 1 & 2 & 3 & 4 & 5 & 6 & 7 & 8 & 9 & 10 \\
\hline & & \multicolumn{10}{|c|}{$\begin{array}{l}\text { Relativna greška površine } \mathrm{u} \% \text { od površine kategorije šume) } \\
\text { Relative eror of estimate in \% of forest categorys area }\end{array}$} \\
\hline \multirow{2}{*}{1100} & formula & 10,1 & 9,9 & 10,1 & 9,8 & 9,5 & 10,1 & 9,5 & 9,8 & 9,6 & 9,4 \\
\hline & stvarna & 6,4 & 1,6 & 7,0 & 0,6 & $-5,1$ & 7,0 & $-4,4$ & 0,1 & -2 , & $-6,1$ \\
\hline \multirow{2}{*}{1200} & formula & 5,6 & 5,6 & 5,7 & 5,6 & 5,6 & 5,5 & 5,5 & 5,6 & & 5,7 \\
\hline & stvarna & 0,2 & 0,6 & 2,5 & $-0,6$ & $-0,5$ & $-2,2$ & $-2,4$ & 0,2 & & 2,3 \\
\hline \multirow{2}{*}{1300} & formula & 14,8 & 14,6 & 14,2 & 14,5 & 14,5 & 15,2 & 14,5 & 14,9 & & 15,5 \\
\hline & stvarna & 3,9 & 1,0 & $-5,2$ & $-0,7$ & $-0,6$ & 8,2 & $-0,8$ & 5,0 & 11, & 11,3 \\
\hline \multirow{2}{*}{1400} & formula & 17,2 & 19,7 & 18,9 & 18,5 & 17,3 & 19,7 & 18,3 & 19,7 & 18 & 18,6 \\
\hline & stvarna & 20,3 & 7,1 & $-0,3$ & $-4,8$ & 18,4 & 7,9 & $-6,1$ & 7,5 & & \\
\hline \multirow{2}{*}{2000} & formula & 23,9 & 24,5 & 23,3 & 26,6 & 25,4 & 25,1 & 24,3 & 25,5 & 25 , & 23,9 \\
\hline & stvarna & $-1,8$ & 2,7 & $-6,9$ & 17,2 & 10,0 & 7,3 & 1,5 & 10,3 & 10,1 & $-1,9$ \\
\hline \multirow{2}{*}{3000} & formula & 14,4 & 14,3 & 14,9 & 15,7 & 15,8 & 13,8 & 14,5 & 14,9 & 14,0 & 15,0 \\
\hline & stvarna & $-3,1$ & $-4,4$ & 4,2 & 13,2 & 14,0 & 11,6 & $-1,7$ & 3,4 & -8 , & 4,5 \\
\hline \multirow{2}{*}{4000} & formula & 10,7 & 10,9 & 10,6 & 9,8 & 10,9 & 10,2 & 10,2 & 11,1 & 10,1 & 10,6 \\
\hline & stvarna & 1,2 & 4,0 & $-0,5$ & 16,8 & 4,9 & $-7,3$ & $-7,7$ & 8,4 & 10,7 & 0,0 \\
\hline \multirow{2}{*}{5000} & formula & 19,4 & 21,6 & 20,4 & 22,8 & 21,5 & 20,9 & 22,4 & 20,4 & 20,4 & 22,4 \\
\hline & stvarna & $-9,9$ & 10,4 & 0,0 & 19,5 & 9,8 & 4,7 & 16,6 & $-0,3$ & 0,3 & 17,0 \\
\hline \multirow{2}{*}{6000} & formula & 15,5 & 16,7 & 14,9 & 15,3 & 15,6 & 15,7 & 16,7 & 16,0 & 15,6 & 15,9 \\
\hline & stvarna & $-3,4$ & 9,5 & 12,0 & $-6,9$ & $-2,4$ & $-1,1$ & 10,3 & 1,9 & $-2,1$ & 0,9 \\
\hline \multirow{2}{*}{7000} & formula & 21,1 & 24,1 & 20,5 & 21,2 & 21,7 & 21,6 & 19,3 & 19,9 & 20,6 & 19,4 \\
\hline & stvarna & 0,5 & 23,1 & $-6,0$ & 1,2 & 5,9 & 4,4 & 18,4 & 12,0 & $-4,8$ & 18,0 \\
\hline \multirow{2}{*}{$\begin{array}{l}\text { Sve } \\
\text { all }\end{array}$} & formula & 2,9 & 3,0 & 2,9 & 2,9 & 2,9 & 2,9 & 2,8 & 2,9 & 2,8 & 2,9 \\
\hline & stvarna & $-0,2$ & 2,8 & 0,8 & $-0,8$ & 0,5 & $-0,2$ & $-2,5$ & 2,0 & $-1,3$ & 1,0 \\
\hline
\end{tabular}

\section{Zaključak - Conclusions}

$\mathrm{Na}$ osnovu prikazanog može se zaključiti da su GIS alati vrlo efikasno sredstvo za analizu različitih formi uzoraka koji se mogu primijeniti u inventurama šuma, posebno $\mathrm{u}$ inventurama šuma na velikim površinama, a radi iznalaženja optimalne forme uzorka.

Testiranjem različitih formi uzoraka za procjenu površina pojedinih kategorija šuma, došlo se do zaključka da je od svih ispitivanih najbolja ona forma i dizajn trakta koji je sastavljen od samo 4 kružne površine smještene u tjemenima kvadrata sa dužinom stranice od $200 \mathrm{~m}$, a koji su sistematski raspoređene u kvadratnoj mreži 2 x 2 km, jer se primjenjujući traktove-clustere pomenutih dimenzija i razmaka sa skoro upola 
manjom površinom obuhvata populacije uzorkom postiže skoro ista ili bolja veličina relativne greške procjene kao i pri primjeni ostalih oblika traktova.

Imajući u vidu i činjenicu da je pored površina za najveći broj elemenata koji će se inventurom utvrđivati (taksacioni i drugi podaci) zajednički centar za sve kružne površine to svakako ide u prilog skraćivanju vremena snimanja što u konačnosti vodi smanjenju troškova na prikupljanju podataka.

Istim testiranjem je i potvrđena ispravnost korištenja formula „proporcija u uzorku“ za procjenu površina šuma i greške procjene istih.

\section{Literatura - References}

1. AKÇA, A. (2001): Waldinventur, Frankfurt am Main.:Sauerländer

2. Kangas, A., Maltamo, M. (2006): Forest Inventory - Methodology and Applications.Springer, Vol.10.Netherlands.

3. KoeHL, M., Pelz,D.R.(1991):Forest Inventories in Eerope with Special Reference to Statistical Methods.Swiss Federal Institute for Forest, Snow and Landscape Research, WSL/FNP, Birmensdorf, 1991

4. KopriviCA, M. (1995): Statistički uzorci. Skripta.Beograd

5. Kromidha, G., Postoli, A., Habili, D., Preto, G. (2001): Albanian National Forest Inventory - ANFI. Ministry of Agriculture and Food of Albania. Tirana.

6. LOJO, A., PONJAVIĆ, M. (2004): Geografski informacioni sistem u gazdovanju prirodnim resursima. Gauss Tuzla.

7. Longley, A. P., GoOdChiLd J.M., MAGUiRe J.D., Rhind W.D. (2001): Geographic Information Systems And Science, John Wiley / Sons, LTD, Chichester, New York, Wienheim, Brisbane, Singapure, Toronto .

8. LÖTSCH, F., ZÖHRER, F., HALLER, K.E. (1973): Forest Inventory.Vol II. BLV München.

9. MATIĆ,V. (1965): Metod inventure šuma za velike površine. I i II dio. Institut za šumarstvo Šumarskog fakulteta u Sarajevu, posebno izdanje, Sarajevo.

10. MATIĆ, V. ET AL (1971): Stanje šuma u SR Bosni I Hercegovini -prema inventuri šuma na velikim površinama u 1964-1968 godini.Posebno izdanje br.7. Šumarski fakultet i Institut za šumarstvo u Sarajevu.

11. Mirković, D. \& BANKOVIĆ, S. (1993): Dendrometrija. Beograd.

12. Preto, G. (2001):Feasibility Study of the Albanian National Forest Inventory. Ministry of Agriculture and Food of Albania.Tirana

13. SCHIELER, K., HAUK, E. (2001): Österreichische Waldinventur 2000/2002 Instruktion für die Feldarbeit.FBVA Waldforschungscentrum, Wien.

14. SChmid-HaAs,P., BAUmann,E., Werner, J. (1993): Forest Inventories by Unmarked Permanent Sample Plots: Instruktions. Swiss Federal Institute for Forest, Snow and Landscape Research, Birmensdorf, 1991

15. SHIVER, B. D., BORDERS, B. E. (1996): Sampling techniques for forest resource inventory. New York, Chichester, Brisbane, Toronto, Singapore: John Wiley \& Sons, Inc.;

16. ZÖHRER, F. (1980): Forstinventur, Hamburg und Berlin. 


\section{Sažetak - Summary}

The paper presents the GIS tools implementation possibilities in testing of the most appropriate shape and optimal number of the exemplary surfaces as the sample units for the assessment of the forest land areas within large area forest inventories..

For testing purpose, we used real data on forest areas in the vector map format, which covers about one tenth of the total area of B\&H. It is $1 / 10$ of forest areas and forest land approximately respectively. All maps are aggregated in one layer, which allows a single map of all forest stands to be produced. At the same time, the data about stands was imported in one data-base table. So we have established one GIS-project. The source of this data were forest management plans (maps) from 8 forest management regions in $\mathrm{B} \& \mathrm{H}$.

On other layers we have created networks of exemplary surfaces in different forms, one form -one layer. All forms were systematically distributed in different square grids, keeping the same covered area - the same rate of selection in the overall sample.

We tried to give answers to 3 questions?

- Which is the best direction (azimuth) for vegetation variability coverage?

- Which shape of the exemplary surfaces gives the best assessment of vegetation variation?

- Is the "proportion sample formula" adequate for forest types area assessment, regarding calculation of accuracy for national forest inventories.

Using the method of overlapping of the layers, and at the same time overlapping of their data bases, one can get quickly to the result which is similar to that from the forest inventory. Upon further statistical analysis of the resulting bases, it is possible to get the answer to the question which one of the sample models is the most representative and which one is giving the closest data on the areas in relation to the real ones.

We have solved the first task with overlays of strip layers, in 4 directions (azimuth) with forest type vector map layer. One strip was a polygon of $1 \mathrm{~m}$ width and more than $100 \mathrm{~km}$ length, so it could cover the overall tested area in all directions. Generally, more intersections of strips and forest type polygons mean better coverage of vegetation variability. There were no statistically significant differences in the results from 4 overlays.

Therefore, the optimal shape of some inventory tracts should not depend on the azimuth orientation. Thus, the tract of an "L" shape or rectangle shape should have equal sides.

Subsequently, as the second task, we created and tested more forms of exemplary surfaces (tracts) see table 2, and figure 3.

All tested models were $20 \mathrm{~m}$ width strips, with different lengths and shapes:

1. line strips with $5600 \mathrm{~m}$ length (azimuth $18^{\circ} 26^{\prime}$ from the north - as in the first National Forest Inventory in B\&H), and 5,056 x $5.056 \mathrm{~km}$ network density, in 2 repetitions; 
2. L strips with $2 \times 2800 \mathrm{~m}$ (azimuth of $0^{\circ}$, and $90^{\circ}$ ) and $5,056 \times 5.056 \mathrm{~km}$ network density, in 2 repetitions;

3. L strips with $2 \times 985 \mathrm{~m}$ (azimuth of $0^{\circ}$, and $90^{\circ}$ ) and $3 \times 3 \mathrm{~km}$ network density, in 2 repetitions;

4. square strips $4 \times 492,5 \mathrm{~m}$, and $3 \times 3 \mathrm{~km}$ network density;

5. square strips $4 \times 218,75 \mathrm{~m}$, and $2 \times 2 \mathrm{~km}$ network density;

6. cluster of 4 circles $(\mathrm{r}=25 \mathrm{~m})$ in square $200 \times 200 \mathrm{~m}$, and $2 \times 2 \mathrm{~km}$ network density, in 10 repetitions;

With statistical analysis of the resulting database after overlays, we obtained the following result. As the optimum, regarding accuracy of the forest area assessment, and the overall sample area, was the square tract of 4 circles $200 \times 200 \mathrm{~m}$ and network density of $2 \times 2 \mathrm{~km}$. Because of that this model was repeated 10 times. The overlay results were used for the „Relative error of estimate formula“(1) testing. The calculated error in \% was bigger than the real error in 106 out of of 110 calculations. The corresponding probability of $95 \%$ was quite well.

This method was used in the process of methodology development for the second state forest inventory in Bosnia and Herzegovina. 